(The 3rd ICBS-2013)

\title{
CONSTRUCTING BALINESE ANALOGY AND PROVERB BASED ON BIOLOGICAL PHENOMENA: THE INITIATIVE OF BALINESE BIODIVERSITY DOCUMENTATION
}

\author{
Suryadarma, I.G.P. \\ Faculty of Mathematic and Science, Yogyakarta State University \\ samodhaya @yahoo.com
}

\section{INTRODUCTION}

The nature is real teacher for a person who wish to develop their intelligence. Intelligence is a natural quality of live. The universe intelligence are hidden everywhere, and if we have eyes to see, we can see it everywhere. We can learn from animals on how they sleep, they live and their interaction each others. Most people in every traditional culture learn based on their beliefs rather than their reason (Suryadarma, 2012). There are many different ways to look the uniqueness of biodiversity and the interrelationship between humans and their social and biophysical surroundings.

People in the past; i.e. hunting and gathering communities were heavily depended on their immediate natural resources to meet most of their basic needs. Therefore, they closely interacted with their environment and thereby, gained a sound knowledge and understanding the uniqueness of each species and its underlying ecological processes. Many events in daily life is interesting, in the sense that many phenomena and objects can be directly observed. The richness of biological pehenomena in the ecosystems can be directly observed. Some phenomena had recorded as a proverbs, analogy and song.

Balinese use the uniqueness of biodiversity resources and ecological phenomena in their daily life to find analogy, proverb and song to reflect their life. Yesudian (1989) declared; that man is the culminating point of the creation but in the man alone are animal, human and divine qualities alive and active together. Which aspects of our nature are to manifest? To manifest the humanity is the purpose of our earthly life (Suryadarma, 2010). This is the reason why the Balinese use proverbs, analogy, and song as part of learning process. Learning is processes of our escalation where it processes e.g. it can be analogized with the process of transformation on butterfly life cycle

Tsunami is a large ocean waves that washes everything in the shallow water of a shoreline where globalization can be analogized with tsunami process in which the world increasingly their activities. Globalization is the fact where the people have been two ways in looking at it impact on their life activities. It is the reason why each person use different ways looking of proverbs, analogy in our cultural activities. How develop its in deferent level and different site into better science for better life? How to explore and develop it as sources of biodiversity documentation information because these activities will be developed the fragrance of ecological wisdom and enter in every one heart.

\section{MATERIALS AND METHODS}

The study area located at Tabanan regencies (kabupaten); that regency was selected 
by purposive sampling. Tabanan Regency is one of regency in Bali where it spread from the coast until mountain area, the cenral of rice production, and it quicly develop to ecotourism. Data of research were obtained from informant through an open discussion. The kind of proverbs, analogy and songs information was obtained by unstructured interviewing from the key persons. Key persons involves both two groups of monk (pendeta), and experts Balinese Language, at Udayana University. The study was carried out during three time periods: January 2011, June 2010 and October 2012. Based on the information and data obtained the scientific vernacular of plants and animals were noted. Intensive Marga Village. A series of informal interviews which to determine to kind of proverb, analogy and songs that based on biological objects. The sequence of construction consists of four steps. Firstly identification of proverbs, analogies, and songs, secondly determination of characteristics biological objects, thirdly determination of scientific name biological objects and the lastly meaningfulness of proverbs, analogies and songs.

\section{RESULT AND DISCUSSIONS}

\section{A. The Common Balinese Knowledge Based on Biodiversity}

The Balinese knowledge which based on the existence of biodiversity was classified into five groups. It knowledge consist of; gegendingan (general of songs), sesimpedan (puzle) perumpamaan (proverbs), sesindiran (analogy) and pergaulan (pleasant). The results indicated 12 kinds of proverbs, 19 analogies and 14 of songs. These biological objects consist of; 120 animals, 52 of plants, and 80 percent of them are clarified in scientific names. The animals can be classified into five groups from the largest to the smallest these are insects, mollusks, amphibians, reptiles, fishes and mammals. The plants are classified into flowering plants, seeds plants and each of those plants has specific feature. The model of construction can be used as source of local biodiversity information

\section{Uniquenss of Animals to Exploring Human Behavior}

The animals and their uniqueness which can be used to explore human character are as follow; dragon fly and their larva, several molusca, frog, eel, red ant, tekukur, duck, crichet, gagak. Biological object and their phenomena in Balinese culture can be used as biodiversity documentation. The document that origin from Balinese initiatives. This knowledge passes from generation to generation, usually by word mouth and it knowledge has been known at least among three generation. The animals that they use to refer it human character are involved several of species, sequence of their reproduction, their uniqueness of habitat, types of form and their sound. For examples; the relationship between their uniqueness dragon fly that use it songs

\section{a. Capung gantung}

Capung gantung lungan tumbak

Capung engkok luangan bedil

Ngelandok-ngelanting

Basang embok gede ceking

d. Capung Ning

Ning ning sir

Meencegan buka lingsir b. Capung Karah Karah karah ketumbah Ketulup kebedil

\section{e. Capung Dem}

Dem dem meng Ngidem cara emeng c. Capung Bera

Bera nyungla

Meencegan jalan mula

f. Tik Klung

Tik tik lung

Mara mentik lantas elung 
The uniqueness of each song that indicated the existence of dragon flies. The description its dragon that use are follows; capung gantung, capung engkok, capung karak capung bera, capung ning, capung dem, and capung tik (Table 1)

Table 1.Description each Characteristic of Dragon Fly .

\begin{tabular}{|c|c|c|c|c|}
\hline No & Local name & English & Scientific Name & Characteristic \\
\hline 1 & $\begin{array}{l}\text { Capung } \\
\text { gantung }\end{array}$ & Dragon fly & Crocothemis erytrachea & $\begin{array}{l}\text { Hanging position, yellow gold colour. } \\
\text { Always flying and hanging when it } \\
\text { sleeps. Eat ony small insect }\end{array}$ \\
\hline 2 & $\begin{array}{l}\text { Capung } \\
\text { engkok }\end{array}$ & Dragon fly & Orthetrum sabina & $\begin{array}{l}\text { Staright position, green and white cross } \\
\text { colour, most hanging rather than fluing }\end{array}$ \\
\hline 3 & Capung karak & Dragon fly & Orthetrum $s p$ & $\begin{array}{l}\text { Most hanging and some time flying, all } \\
\text { part of body red colour }\end{array}$ \\
\hline 4 & Capung ning & Dragon fly & Orthetrum $s p$ & $\begin{array}{l}\text { Most hanging and some time flying, all } \\
\text { part of body yellow colour }\end{array}$ \\
\hline 5 & Capung dem & Dragon fly & Orthetrum $s p$ & $\begin{array}{l}\text { Most hanging and some time flying } \\
\text { when cat the prey, all part of body } \\
\text { orange colour }\end{array}$ \\
\hline 6 & Capung bera & Dragon fly & Orthetrum $s p$ & $\begin{array}{l}\text { Most hanging and some time flying, } \\
\text { when cat the prey and back the same } \\
\text { place, all part of body blublack colour }\end{array}$ \\
\hline 7 & Capung tik & Dragon fly & Orthetrum $s p$ & $\begin{array}{l}\text { Most hanging and some time flying, } \\
\text { when cat a prey, green-yelow colour }\end{array}$ \\
\hline
\end{tabular}

Exploring and using uniqueness dragon fly as a song indicated the existence the range of types dragon fly in community and in their species. Now decreasing rice field that causing the existence dragon fly were in critical situation. Many children and their village and especially the children in the city did not know dragon fly. It means why meaningfull watching dragon flies become important to develop a songs, analogy and proverbs. When we are watching something, we can only see the figure outside- when we are watching something the figure it can create a certain situation inside. Like watching pop modern music performance whos every person becomes more excised sexually. There is nothing about sound outside but the sound hits inside, creates something inside our mind (Osso, 2003) Watching the uniqueness of dragon flies create a figure inside our mind and that inside figure create a certain vibration. It was not just imagination that happened in our mind. It has it situation analogy with seed encloses in the shell. Just as a seed encloses the possibility of a tree, so child bears within himself a divine core which he must one day make fully manifest

\section{Using of Proverb}

Exploring the relationship among behavior of each animals were described in the proverbs Blatuk Ngulkul where a bird hammers the stem of tree. 
Balinese Proverb

Tuk tuk tuk

Ngudiang I kedis blatuk ngulku?

I capung engkok ngabe tumbak poleng

Ngudiang capung engkok ngaba tumbak poleng? I kunang-kunang ngaba api

Ngudiang I kunang-kunang ngaba api?

I Bedude ne peteng-peteng ngurek tahin sampi

Ngudiang I beduda ngurek tain sampi?

I sampi meju dijalane

Ngudiang I sampi menju dijalane?

Dije men cang meju dadi di bungut Dewane meju

Plok bungut I sampi dipukul Btatare Guru

Ento ngranang bungut I sampi tusing ngelah gigi.
Meaning of proverbs

Tuk tuk tuk...tuk

Why blatuk bird hames the wood drum?

Because yellow dragon fly handle the black white stick

Why the yellow dragon fly handle it sticks?

Because fire fly prepare a fire

Why the fire fly prepare a fire?

Because the black insects eating faeces of a cow

Why the black insect eating cow faeces?

Because the cow faecing in the road

Why the cow faecing in the road?

The cow asked to Deva Guru who as teacher of knowledge Where I am must faecing?

My I am faecing in mouth of Deva of Teacher?

Crakks...the mouth of cow was hammered by Deva Teacher

Than all the theeth of cow on the upper jaww are falled

That the cause why a cow doesn't have a teeth a upper jaw

Proverbs Blatuk Ngulkuldialogies were described the interacting among animals which declared in the law of cause-effect. That interdependency among them it analog with the food chain and food web in ecological aspects. Number of animals and each characteristic that were used five animals (Table 2)

Table 2. Number of Animals and Each Characteristic

\begin{tabular}{|c|c|c|c|c|}
\hline Number & Local Name & English & $\begin{array}{l}\text { Scientific } \\
\text { Name }\end{array}$ & $\begin{array}{c}\text { Characteristic of Each Animal } \\
\text { in their Activities }\end{array}$ \\
\hline 1 & Blatuk & $\begin{array}{l}\text { Burung } \\
\text { pelatuk }\end{array}$ & $\begin{array}{l}\text { Picoides } \\
\text { tridactylus }\end{array}$ & $\begin{array}{l}\text { Sound like wood drum (kulkul) when the } \\
\text { chops of bird to hammer the stem plant. }\end{array}$ \\
\hline 2 & $\begin{array}{l}\text { Capung } \\
\text { engkok }\end{array}$ & Dragon fly & $\begin{array}{l}\text { Orthetrum } \\
\text { Sabina }\end{array}$ & $\begin{array}{l}\text { Dragon fly wchic has a long tail it tail signing } \\
\text { with black-white line, like Balinese black - } \\
\text { white spear. }\end{array}$ \\
\hline 3 & $\begin{array}{l}\text { Kunang } \\
\text { kunang }\end{array}$ & Fire fly & $\begin{array}{l}\text { Cyphonocerus } \\
\text { ruficollis }\end{array}$ & $\begin{array}{l}\text { The lighting of animal like a person who a } \\
\text { person handel fire }\end{array}$ \\
\hline 4 & Beduda & Black Insect & & $\begin{array}{l}\text { Blacck insect when it eating a faeces of cow } \\
\text { where it faeces enough energy }\end{array}$ \\
\hline 5 & Sampi & Cow & Bos Taurus & $\begin{array}{l}\text { The faeces of cow spread in a long of road } \\
\text { where it faeces eating by black insect }\end{array}$ \\
\hline
\end{tabular}

Interaction among animals can be the indicator of cause-effect of law. The ends of causeeffect law were finished when whos Dev Guru hammer the jaw of cow. It is the answer why cow does not has teeth at the the upper jaw. These phenomena are supported by philosophy of deep ecology (Arness, 1985). Deep ecology is to developed by focusing on deep experience, deep questioning and deep commitment. The well-being and flourishing of human and nonhuman life on Earth have value in themselves, richness and diversity of life forms to contribute the realization of these values and are also values in themselves

The constructing biodiversity information system that are consists of; local name, English, scientific name and their completely with meaningfull each characteristics of aimals. There are 27 kind of animals were used to explore human character (Table 3) 
Table 3. Characteristics of Animals to Explore the Human Character

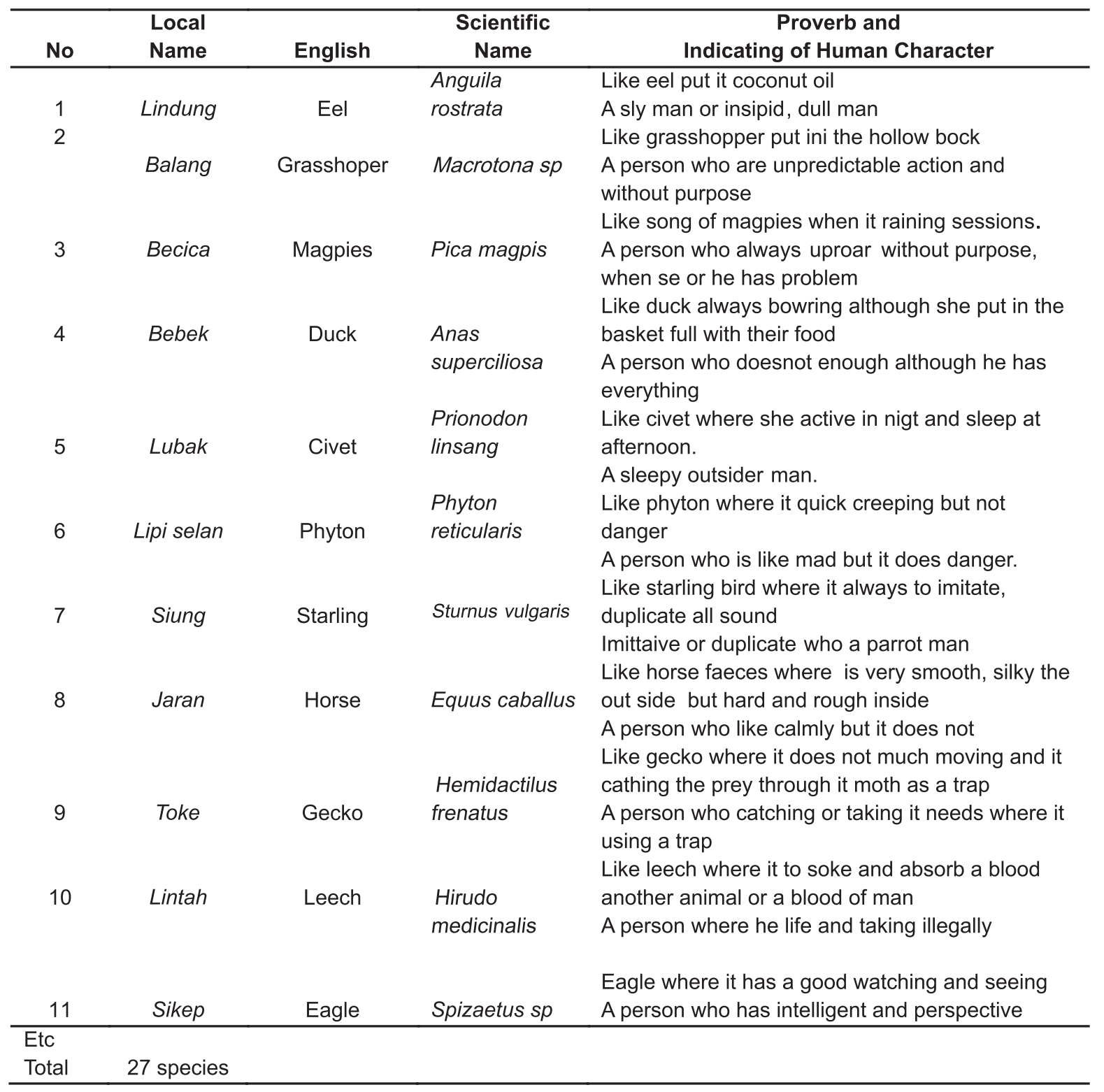

Using proverbs to indicating of human character based on the reincarnation principle.is very important for Balinese. One who is born must die some day, and one that dies is born again, and thus the continuity of life is maintained. Although human is culminating point of the creation but in the man alone are animal, human and divine qualities alive and active together. Balinese philosophy which based on Tatwamasi (he is you), Vasudhaiva Katumbakam, everything on this earth are brothers and not others, Tri Hita Karana, and three things lead to a prosperous and hapy life (Titib, 2013). It principle was supported by the central spiritual tenet of deep ecology (Arness, 1985). Man species is a part of the Earth and not separate from it. A process of self-realisation is used for an individual to intuitively gain an ecocentric perspective. The notion is based on the idea that the more we expand the self to identify with "others" (people, animals, ecosystems), the more we realize ourselves.

Number of animals and each characteristic that were used at the Blatuk Ngulkul proverbs are twelve species (Table 4) 
Table 4. Number of Animals and Each Characteristic

\begin{tabular}{|c|c|c|c|c|}
\hline Number & $\begin{array}{l}\text { Local } \\
\text { Name }\end{array}$ & English & Scientific Name & $\begin{array}{l}\text { Characteristic of Animal and } \\
\text { Indicating of Human Character }\end{array}$ \\
\hline 1 & Kekket & Putri malu & $\begin{array}{l}\text { Caesalpinia } \\
\text { bonducella }\end{array}$ & $\begin{array}{l}\text { Shrubs where it has pointed in the stem and it } \\
\text { stem always cathing in all side } \\
\text { A trouble man where he or she life } \\
\text { It fruits contaoins strong tannin it caused }\end{array}$ \\
\hline 2 & Buah & Areca & Areca catechu $L$ & $\begin{array}{l}\text { poisonous } \\
\text { A poison person when he chewing areca fruit }\end{array}$ \\
\hline 3 & Mako & Tobacco & Nicotiana tabacum & $\begin{array}{l}\text { Like a poison person when she or he chewing } \\
\text { tobacco }\end{array}$ \\
\hline & & & & \\
\hline 5 & Janggu & Fennel flag & Acorus calamus & $\begin{array}{l}\text { Propocate man } \\
\text { Like stem of banana where it cool and much }\end{array}$ \\
\hline 6 & Gedebom & Banana & Musa paradisiaca & $\begin{array}{l}\text { more water } \\
\text { Frigide women although she has a big body }\end{array}$ \\
\hline & Tabia & & & Like chilli paper that is small but has hot taste \\
\hline 8 & krinyi & Chilli paper & Capsicum fructecens & $\begin{array}{l}\text { Like a little man but he or she has many } \\
\text { potentialities }\end{array}$ \\
\hline 9 & $\begin{array}{l}\text { Nyuh } \\
\text { gading }\end{array}$ & $\begin{array}{l}\text { Yellow } \\
\text { coconut }\end{array}$ & Cocos nucifera & $\begin{array}{l}\text { The smoth form of fruit yellow coconut and } \\
\text { erected position } \\
\text { Like mame a girl who has god form, and } \\
\text { staright position }\end{array}$ \\
\hline 10 & Candung & Water taro & $\begin{array}{l}\text { Colocasia } \\
\text { esculentum }\end{array}$ & $\begin{array}{l}\text { Like taro leaf where it surface very smooth } \\
\text { When put a drop a water tha twater will fall } \\
\text { Like a person when he or she in critical } \\
\text { position }\end{array}$ \\
\hline 11 & Padi & Rice & Oriza sativa & $\begin{array}{l}\text { The stem it plants is straight and smooth } \\
\text { Like a women who has a smoot and a long } \\
\text { thigh }\end{array}$ \\
\hline \multicolumn{5}{|r|}{ 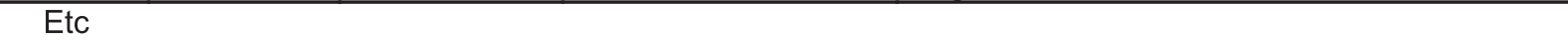 } \\
\hline Total & 27 & & & \\
\hline
\end{tabular}

Balinese farmer families have a wide knowledge of their rice field and ways using it to sustainably.life. Plants not only physical but plants also known as vanaspati. Lord Himselfs is vanaspati, the Master of Forests (Av, III.8). How we are integrating it into scientific biodiversity information and promoting it into environmental education. The basic principles of Environmental Education (Fien at al., 1997) at least are involves; to recognizes the value of local knowledge, practices and perceptions in enchancing sustainability and integrated aspects of ecological, political, natural, technological, sociological, aesthetic. It develops awareness and explores not only the physical qualities of the human relationship with the environment, but also the spiritual aspect of the relationship. Why Balinese are linked with nalogy, provebs and song that based on biodiversity? It philosophy based on Man's family RGVEDASAMHITA (Sarasvati, 1977). Man's family not only includes men, but a few domesdicated creatures also, known as gramya-pasu or cattle with the total five. It cattle are; asva (horse), go (cow), aja (goat), avi (ewe) and manysya (man). From the cosmic sacrifice were produced curd and butter and from the same were born animals of three catagories: (1) vayavya (flying animals), (2) gramya (catle) and (3) aranya (wild) (Rv X.90.8). Balinese calendar classified five week each month where each week refer to the taru (plants), buku (nodes plants), mina (fish), sato (animals), and, wong (men). Watson (1991), declared; all agree that there are two viable metaphysical systems, and that the truth lies in reconciliation between them. It is im- 
possible to distinguish between the two groups of quotations. Scientist who sees everything's is isolation, and the other mystic who experience only a featureless flow. That is the essential meaning why scientist supports the local initiative knowledge to promoting biodiversity documentation

\section{REFFERENCES}

Fien, J. 1977. Education for Sustainability . In: Fien, J., D. Heck, A. Ferreira (editors). Learning for a Sustainable Environment. UNESCO Asia-Pacipic Centre of Educational Innovation for Development and Griffith University Centre.

Naess, A. The Shallow and the Deep. Long Range Ecology Movement. Summary

Sarasvati, P., S. Satya, and S. Vidyalankar. 1977. RGVEDA SAMHITA. Vol I. Published by the Veda Pratishthana, New Delhi.

Osho. 2003. Tantra Vision. The Door to Nirwana. New Delhi.

Suryadarma. 2012. Adapting Uniqueness of Fable as Source of Ecological Information. Internatiomal Procedding Yogyakarta State University.

Titib, IM. 2013. Some Aspects of Hinduism in Bali. Working Committee World Hindu Summit 2013. Penerbit PARAMITA Surabaya

Yukteswar, G.J.S. 1997. The Holy Science. Published by Self-Realization llowship. Los Amgeles, California.

Watson, L. 1991. Gift of Unknown Things. Destiny Books. Originally Published, New York. 